\title{
Perspectives on the wasting disease of eelgrass Zostera marina
}

\author{
Lisa K. Muehlstein* \\ Department of Botany, University of Georgia, Athens, Georgia 30602, USA
}

\begin{abstract}
Early in the 1930's a major epidemic decimated populations of eelgrass Zostera marina L. along the Atlantic coast of North America and Europe. Over $90 \%$ of the eelgrass populations disappeared, resulting in dramatic changes within the coastal ecosystem. There was much speculation about the possible causes of the wasting disease ranging from pathogenic microorganisms to abiotic factors including changes in temperature, precipitation, salinity, and pollution. In a critical review of the literature, substantial research supported the view that a species of the genus Labyrinthula, a marine slime mold, was the primary causative agent of the epidemic disease. This hypothesis was consistently supported by data collected throughout the range of diseased eelgrass populations. In the present recurrence of eelgrass wasting disease, a pathogenic species, Labyrinthula zosterae has been identified as the causative agent of the disease. Similarities of past and present wasting disease episodes further support the hypothesis that Labyrinthula is the primary etiological agent.
\end{abstract}

\section{INTRODUCTION}

The wasting disease of eelgrass Zostera marina has been a concern to scientists for over 50 yr. There is an abundance of literature dating from the 1930 's to the present speculating about the actual causes of the catastrophic decline of eelgrass (Fischer-Piette et al. 1932, Duncan 1933, Mounce \& Diehl 1934, Renn 1935, Stevens 1936a, Tutin 1938, Martin 1954, McRoy 1966, den Hartog 1987), the ecological effects of the major decline (Cottam 1933a, b, McNab 1934, Stauffer 1937. Dreyer \& Castle 1941, Moffitt \& Cottam 1941, Addy \& Aylward 1944, Dexter 1944), and the present day recurrence of a similar wasting disease of eelgrass (Short et al. 1986, 1987, 1988, Muehlstein et al. 1988). Several publications have reviewed the wasting disease of eelgrass (Milne \& Milne 1951, Johnson \& Sparrow 1961, Pokorny 1967, Rasmussen 1973, 1977, Thayer 1984, den Hartog 1987, Short et al. 1988) but a comprehensive examination of the literature has not been completed. This review offers an examination of

\footnotetext{
- Present address: Caribbean Research Institute, University of the Virgin Islands, St. Thomas 00802, U.S. Virgin Islands
}

the many aspects of wasting disease of eelgrass $Z$. marina, from the past and present literature, in an attempt to more clearly elucidate one of the major epidemic diseases in the marine ecosystem. Many hypotheses have been formulated about the causes of the past epidemic wasting disease. This review presents a complete look at the hypotheses, the data bases of the hypotheses, and the evidence presented against some of the hypotheses. It also examines the significance of eelgrass and the resulting problems from the loss of the seagrass in the $1930^{\circ} \mathrm{s}$

There were reports of declines in eelgrass populations prior to the $1930^{\prime} \mathrm{s}$ but none were as catastrophic as that of the 1930's (Cottam 1934a, b). Historical records indicated a period of decline in 1893-1894 along the Atlantic coast of North America from Nova Scotia to North Carolina as well as in England and France (Cottam 1934a, 1935b, McNab 1934, Lami 1935). The extent of disappearance and deleterious effects of the previous declines were not well documented (Cottam 1934a). McNab (1934) recalled that it took 5 to 6 yr for the eelgrass to reappear in Nova Scotia. Butcher $(1934,1941)$ reported 2 distinct periods of eelgrass deterioration in England, one in the early 
$1920^{\prime}$ s and the other in the early 1930's. There was no conclusive evidence linking the cause of previous declines in eelgrass populations to the epidemic of wasting disease of the 1930's.

In the early 1930 's vast populations of Zostera marina along the Atlantic coasts of North America and Europe were devastated by an unexplained wasting disease. The first published report documenting evidence of this disease of eelgrass was from Huntsman (1932). The decreases in eelgrass populations were not actually noticed until after the first reports of declines in waterfowl populations in Nova Scotia (Huntsman 1932). It appeared that the disease may have started in Virginia as early as 1930 and then spread northward along the Atlantic coast (Huntsman 1932). Subsequent reports of the extreme devastation of eelgrass populations in North America (Lewis 1932, Cottam 1933a, Cotton 1933a, Lewis \& Taylor 1933, Stevens 1933, 1935, 1936b, Taylor 1933, Renn 1934) and Europe (Fischer-Piette et al. 1932, Blegvad 1934, Butcher 1934, Renouf 1934, Whelan \& Cullinane 1987) were soon to follow. Zenkevitch (1963) reported that eelgrass also was decimated in the Black Sea during the 1930's epidemic. By the fall of 1931 , more than $90 \%$ of the Atlantic coast eelgrass had disappeared, $99 \%$ of the eelgrass populations were gone a year later (Cottam 1933a, Tutin 1942). The only remaining eelgrass plants were in low saline areas (Huntsman 1932, Young 1938a). By the spring of 1933, the Canadian coast south of the Gulf of St. Lawrence had undergone a similar devastation (Cottam 1934a, b).

The symptoms of the disease initially appeared on the leaves of the plants as small dark spots and streaks (Huntsman 1932, Cottam 1933a, Blegvad 1934, Renn 1936a, Young 1937, Van der Werff 1938), progressing to larger blackened patches and streaks on the leaves at a rate of 3 to $5 \mathrm{~cm} \mathrm{~d}^{-1}$ (Renn 1936a). Death of the plant followed due to loss of photosynthetic function of the leaves and eventual exhaustion of the food supply in the rhizomes (Renn 1936a, Young 1937).

In the early 1930's there were no reported declines of eelgrass along the Pacific coast of North America (Cottam 1933a, 1935a, 1938, Cotton 1933a, Stevens 1933. Young 1938b). However, diseased plant tissue was found in examination of eelgrass specimens collected from Nanaimo, British Columbia in late 1936 and 1937 (Young 1938b). Reports along the California coast indicated a scarcity of eelgrass in some bays, but at the time there was no indication of significant disease or reduction in other eelgrass populations along the Pacific coast (Cottam 1939). Moffitt \& Cottam (1941) documented declines in Tomales Bay, Drakes Bay, Bolinas Bay, Morro Bay and Mission Bay along the California coast. Renn examined plant material from these areas and it showed symptoms of disease although he was not able to isolate Labyrinthula, the suspected pathogen, from the leaves (Moffitt \& Cottam 1941). Reports from Washington state indicated a steady decline in eelgrass populations over the $5 \mathrm{yr}$ prior to 1941 (Moffitt \& Cottam 1941), with the appearance of disease symptoms similar to those reported by Renn $(1934,1936 a)$. In later collections of eelgrass from California, Renn (1942) was able to clearly demonstrate the presence of Labyrinthula in the plant tissue. Although there were declines in eelgrass populations along the Pacific coast, losses were less than on the Atlantic coast (Moffitt \& Cottam 1941, Renn 1942).

After the 1930's epidemic, recovery of the eelgrass populations was very slow. In 1935 Cottam (1935a) reported the conditions of various eelgrass populations throughout North America and Europe. Eelgrass populations in New Jersey, New York, and New England were showing little improvement and some decline, while areas in Delaware, Maryland, Virginia, and North Carolina were showing some signs of improvement (Cottam 1935a). No noticeable increase in eelgrass populations in Canada and Europe had been observed by 1935 (Cottam 1935a). In general, the local populations that were beginning to recover were those in brackish water, while other more saline areas remained barren of eelgrass (Cottam 1935a). Although by 1937 there was slight improvement in the eelgrass situation along the Atlantic coast, with increases in plant density, some areas still seemed to be susceptible to disease and small frequent die-offs were occurring (Lynch \& Cottam 1937). In reviewing the eelgrass situation along the Atlantic coast in 1937, Lynch \& Cottam (1937) and Cottam (1938) concluded that, in general, eelgrass populations were improving based on surveys of extent of coverage. By 1938, populations in Chesapeake Bay, Maryland, northern Virginia, and Shinnecock Bay, New York were almost back to coverage and density of eelgrass prior to the epidemic (Cottam 1938).

By early 1944 the conditions along the entire East coast were improving with a steady recovery apparent along the east coast but late in the summer of 1944 the wasting disease reappeared in Massachusetts and Chesapeake Bay and destroyed some newly recovered eelgrass populations (Cottam 1945). After the brief recurrence in 1944 there appeared to be a steady recovery of the eelgrass populations (Dexter 1945 , 1946, 1947, 1951, Cottam \& Addy 1947. Cottam \& Munro 1954). By the early 1950's the eelgrass along the Atlantic coast of Canada and the United States was al.most completely reestablished in most areas, although eelgrass remained conspicuously absent from areas where it was formerly abundant in southern New Jersey, isolated bays in Connecticut, southern New Jersey, Delaware, Chincoteague Bay in Maryland, and Virginia (Cottam \& Munro 1954). 
In 1984 a recurrence of eelgrass wasting disease was documented in Maine, New Hampshire, and Massachusetts (Dexter 1985, Short et al. 1986). Significant declines in some eelgrass populations were observed (Short et al. 1986, 1987, 1988) and disease symptoms were reported in populations throughout North America and Europe (Muehlstein et al. 1988, Short et al. 1988). Many similarities between the past epidemic wasting disease of eelgrass and the present wasting disease exist (Short et al. 1988).

\section{HYPOTHESIZED CAUSES OF WASTING DISEASE}

During the 1930's there was much speculation about the actual causes of eelgrass wasting disease and this has continued up to the present. While numerous hypotheses were presented, researchers were unable to positively identify the causative agent of eelgrass wasting disease of the 1930's and 1940's, or even whether it was biotic or abiotic in origin. The hypothesized causes ranged from biotic factors of bacteria or fungi (Fischer-Piette et al. 1932, Mounce \& Diehl 1934, Petersen 1934, 1935, 1936, Renn 1934, 1935, 1936a, Tutin 1934, Lami 1935, Young 1937, 1943) to abiotic causative factors including pollution (Duncan 1933), drought (Martin 1954), levels of sunshine (Tutin 1938), declination of the moon (Stevens 1936a), changes in temperature (McRoy 1966), and local explanations (temperature, precipitation, solar cycles) related to individual declines (den Hartog 1987).

Each of the different hypotheses presented during the 1930's and 1940's deserves further discussion. Various changes in environmental conditions were suggested as primary factors causing the wasting disease of eelgrass. Duncan (1933) documented increases in crude oil waste from ships in the English Channel over a 10 yr period prior to the onset of the wasting disease in England. He speculated that perhaps the increase in oil waste was at least locally responsible for the dramatic loss in eelgrass populations. Cotton (1933b) responded quickly to the hypothesis of oil waste, discounting it based on the rapid disappearance of the plant over a very wide range, the general disappearance over this range irrespective of oil pollution, and the continued existence of eelgrass populations in polluted areas. Tutin (1938) also disputed Duncan's hypothesis of oil waste as a cause of the disease. He felt that there was actually a decrease in the total amount of oil discharged in England during the period of the early 1930's. Tutin (1938) also pointed out that if oil pollution was the cause of the wasting disease, then the deep water eelgrass beds should not have been affected. In reality, these deep water beds were devastated the most (Tutin 1938).
Precipitation was also suggested to be correlated with the decline in eelgrass populations (Martin 1954) because the worst drought in the recorded history of the Atlantic coast occurred in 1930. In 1930, precipitation was on the average $25 \%$ below the average normal level of that recorded from 1880 to 1950 . Although there was no drought along the European coast in 1930 . there was a severe one in 1921, the time that Butcher (1941) reported the beginning of the eelgrass decline in England. However, in correlating previous eelgrass declines in Europe with precipitation, den Hartog (1987) points out the discrepancy with Martin's hypothesis. Martin (1954) contradicted himself when he showed that the values for precipitation in western Europe were 15 to $20 \%$ above normal in 1930 . In periodic surveys of eelgrass populations at Cape Ann, Massachusetts, from 1933 to 1984, Dexter (1985) concluded that high precipitation (which in turn lowered estuarine salinities) was favorable for eelgrass recovery at Cape Ann although low precipitation years during 1933 to 1984 were not detrimental to eelgrass recovery.

Stevens (1936a) suggested that declination of the moon was the cause of the wasting disease of eelgrass. He concluded that since 3 dissimilar parasites had been identified on eelgrass, it was not possible to support one or all of the parasites as the ultimate cause of the disease (Stevens 1936a). In examining the historical record, Stevens (1936a) found that 3 recorded periods of eelgrass declines of 1894, 1913, and 1931 correlated with periods of extreme norther declination of the moon which may have caused changes in sea currents, which might in turn alter weather conditions. He noted the coincidence of eelgrass wasting disease with bacterial wilt of corn, which was correlated with weather conditions. Stevens et al. (1950) later retracted this hypothesis as the lunar declination would not alter ocean currents, but only tidal amplitude. He did suggest the alternative that the density of seawater was above normal in 1931 in Atlantic coastal waters and could be correlated with outbreaks of disease in New Jersey and Maine. The change in density was more than likely due to a change in the salinity of the water It was observed by many (Cottam 1938, 1941, Young 1938a) that eelgrass in lower salinities was not severely affected by the wasting disease.

Tutin (1938) reported symptoms of disease in Zostera marina and $Z$. hornemanniana. Labyrinthula was associated with the diseased tissue. Tutin (1938) concluded that since 2 parasites (Labyrinthula and Lulworthia) were present consistently in the diseased eelgrass plants, some change in the growth of the plant allowed for the parasites to become pathogenic. Tutin (1938) offered the hypothesis that low sunlight (insolation) levels caused eelgrass plants to become more susceptible to wasting disease. In 1931 to 1932 there was a 
decrease in the sunshine of over $20 \%$ in the British Isles with limited data supporting this general phenomenon in several other countries. However, data on exactly which other countries had a decrease in sunshine were not available (Tutin 1938). In examining the records for insolation levels from 1897 to 1937, Atkins (1938) concluded that there was nothing unusual about the 1931 to 1932 low values of sunlight because on the basis of the extended record, there had been an average $20 \%$ decrease of sunlight in several English districts several times during the period from 1897 to 1937. Atkins therefore concluded that there was no basis for attributing the eelgrass wasting disease to a decrease in insolation. Stevens (1939) examined the sunshine data from 1915 to 1934 for the U. S. and again found no significant variation in the levels of illumination and therefore no direct correlation with the wasting disease. Glemarec (1979) described a 50 to 55 yr solar cycle, known as the cycle of Russell (Southward et al. 1975) which correlated with the decline of eelgrass in 1930 to 1935 but he did not implicate the cycle as a cause for the decline in eelgrass.

Temperature was the one environmental factor which gained some recognition as a plausible causative factor responsible for the eelgrass wasting disease. Setchell $(1922,1929)$ described fairly strict temperature ranges for Zostera marina based on observations of eelgrass in the field and in the laboratory. Setchell $(1922,1929)$ documented that the optimal temperature range for growth and reproduction in eelgrass was 10 to $20^{\circ} \mathrm{C}$. McRoy (1966) first introduced the hypothesis that increased water temperature caused the disease. He noticed that abnormally high temperatures $\left(>20^{\circ} \mathrm{C}\right)$ in some tidepools in Izembek Lagoon, Alaska preceded the appearance of symptoms in the eelgrass plants similar to those described for the wasting disease. McRoy (1966) concluded from his observations in Alaska that the wasting disease of the 1930's and 1940's may have been caused by the lethal effects of high temperature. However, McRoy (1966) failed to present any temperature data from the 1930's and 1940 's which would support his hypothesis of temperature as the causative factor of eelgrass wasting disease.

Rasmussen $(1973,1977)$ examined several different hypotheses for eelgrass wasting disease and for various reasons discounted all of the possibilities except the increase in temperature. In examining the temperature data for Denmark he was able to show a precise correlation between fluctuations in eelgrass populations and water temperature. He suggested that the higher water temperature weakened the plants. In 1968 eelgrass populations in some areas around Denmark were destroyed (Rasmussen 1977) and symptoms of wasting disease similar to those described from the previous epidemic of the 1930's were present (Rasmussen 1977).
The decline in eelgrass populations also corresponded with the warmest summer since 1959 in Denmark. Examination of the ecosystem dynamics lead McRoy \& Bridges (1974) to the conclusion that the catastrophic elimination of eelgrass was a natural phenomenon resulting from extremely high water temperatures during the 1930's epidemic. Den Hartog (1987) suggested that the temperature hypothesis was only pertinent for Denmark and did not apply to all areas. An examination of the temperature record for the Netherlands did not support increased temperature as a possible cause for the decline of eelgrass in the 1930's in the Netherlands (den Hartog 1987).

Although there were many different hypotheses presented over the years attempting to explain eelgrass wasting disease, den Hartog (1987) concluded that the wasting disease of the 1930's remained largely unexplained. In a careful investigation of eelgrass declines, fluctuations in year-to-year growth patterns of eelgrass appeared to exist in the Netherlands. According to den Hartog (1987), local changes in conditions including drought, temperature, pollution, solar cycles, and turbidity could account for many of the declines of eelgrass.

Several different hypotheses of biotic causes for eelgrass wasting disease also were introduced. One of the first hypotheses developed by French scientists suggested that a bacterial infection was the cause of the wasting disease (Fischer-Piette et al. 1932, Lami 1935). They were able to isolate a Gram-negative bacterium from the diseased plant tissue and reported an abundance of bacteria within the diseased eelgrass leaf tissue (Fischer-Piette et al. 1932). This hypothesis however was not widely accepted by others (Renn 1934, Petersen 1935). Renn (1934) isolated a number of different bacteria from the diseased plant tissue but was not able to demonstrate any direct association with the disease symptoms nor was he able to demonstrate pathogenicity satisfactorily in inoculation tests (Renn 1936a). Research on the present eelgrass wasting disease also does not support bacteria as a causative factor. of the disease (Muehistein 1989). In laboratory disease tests with bacterial assemblages, no disease symptoms were produced and microscopic examination of diseased leaves revealed no evidence of bacteria (Muehlstein 1989)

Other scientists suggested that an ascomycetous fungus was the cause of eelgrass wasting disease (Petersen 1933, 1934, 1935, 1936, Mounce \& Diehl 1934). Mounce \& Diehl (1934) consistently found perithecia in shoots of plants collected from St. Andrews, New Brunswick, Canada, and mature perithecia in rhizomes of diseased plants. Mounce \& Diehl (1934) described the ascomycete as Lulworthia halima (Diehl and Mounce) Cribb and Cribb 
(= Ophiobolus halimus Diehl and Mounce), parasitic on leaves of Zostera marina in culture and occurring naturally on rhizomes and bases of fertile shoots of $Z$. marina. Petersen (1933) was the first to report an association of a fungus with coarse mycelium and the blackened spots on the leaves. He further described finding perithecia in the rhizomes and identified ascospores belonging to the genus Lulworthia (Petersen 1934) and later suggested that the disease was transmitted by senescent leaves from diseased plants coming in contact with healthy plants (Petersen 1935). He was able to isolate and culture the fungus and demonstrated an abundance of Lulworthia in material sent to him by Renn, who was also working on the problem of wasting disease at that time (Petersen 1935). Petersen (1935) found that the mycelium was able to penetrate into eelgrass leaves but that in most cases, the healthy eelgrass was infected by spores. Tutin (1934) initially supported Lulworthia as a possible cause of eelgrass wasting disease because of its widespread occurrence on diseased eelgrass. Renn $(1935,1936$ a) however was unable to find Lulworthia consistently associated with the diseased leaf tissue. Furthermore, the fungal mycelium did not appear in the leaf tissue following field inoculation tests which involved clamping a diseased piece of eelgrass to a healthy leaf of eelgrass (Renn 1936a).

Perhaps the organism which received the most widespread attention as the causative organism in eelgrass wasting disease was a species of marine slime mold, Labyrinthula, found by Renn (1934) in his initial examination of diseased eelgrass leaf material. Renn was unable to find evidence of bacterial pathogenicity and he did not detect fungal mycelium or perithecia of Lulworthia consistently in his samples of diseased eelgrass. Renn (1934, 1936a) and Young (1938a) described Labyrinthula as forming net-like aggregates in the air spaces of the plant leaves. This parasite, a species of Labyrinthula, was found consistently in eelgrass along the Atlantic coasts of North America and Europe (Renn 1935, 1936a, b, Van der Werff 1938). Although Renn (1936a) was unsuccessful in culturing Labyrinthula, he carried out extensive laboratory and field work studying the disease process. Renn (1936a) made extensive descriptions of the damage caused by the parasite within the plant cells and also observed Labyrinthula in advance of the visible necrotic spots and streaking. He described deterioration of plant cells in diseased leaves including disorganization of chloroplasts and disintegration of the plant cell nuclei. With the breakdown of the nuclei, 'dark, resinous inclusions' appeared along the plant cell walls (Renn 1936a).

In field inoculation studies, Renn (1936a) attached small pieces of diseased eelgrass to healthy plants, and found over $50 \%$ of the healthy plants showed the characteristic darkening and streaking of the leaves $2 \mathrm{~d}$ after inoculation. Renn (1936a) concluded that Labyrinthula was the only organism transferred in a time interval that correlated with the rapid spread of the disease. In his continued work, Renn (1936b, 1937) observed the 'decreased activity' of Labyrinthula during the winter corresponding to few disease symptoms and the 'increased vigor' of the parasite early in the summer, corresponding to the increase in disease symptoms. He confirmed the presence of Labyrinthula in the diseased leaves of eelgrass in all his collections (number unreported) along the east coast of the USA (Renn 1936b). Examination of diseased eelgrass leaves collected on the Pacific coast of Canada revealed Labyrinthula identical to the east coast parasite (Young 1938b). Renn (1942) also identified the parasite in diseased plant material collected from California.

In physiological studies of Labyrinthula using hanging drop cultures, Young $(1938 a, 1943)$ documented a decrease in the physiological activity of the pathogen at lower salinities, with the cells losing their color and their cohesiveness with the network used for motility. This observation correlated well with the survival of eelgrass in low salinity areas and the apparent absence of Labyrinthula in those samples of eelgrass (Young 1938a, 1943). Young $(1938 a, 1943)$ observed that the optimum range of salinity for Labyrinthula was between 12.1 and $17.7 \mathrm{ppt}$ (conversion of chlorinity measurements according to Pokorny 1967). From field observations, it appeared that when salinities in the eelgrass populations increased above about $12 \mathrm{ppt}$, an increase in disease symptoms was apparent. The eelgrass populations in lower salinities ( 8 to $12 \mathrm{ppt}$ ) did not appear to be as susceptible to wasting disease and declines were not observed until salinities increased above 12 ppt (Young 1938b, 1943). Young (1938a, 1943) concluded that changes in salinity were an important secondary factor in wasting disease of eelgrass and difference in salinity was one possible explanation for the local variations observed in the symptoms and declines of the eelgrass populations.

Because Renn (1935, 1936a, 1937) and Young (1937. 1938a, 1943) had consistent results and presented convincing evidence that a species of Labyrinthula was the pathogen responsible for the wasting disease epidemic of eelgrass, this hypothesis was widely promoted in reviews (Milne \& Milne 1951, Hopkins 1957, Johnson \& Sparrow 1961, Pokorny 1967, Olive 1975). Young (1937, 1943) made a detailed description of the parasite and tentatively identified it as L. macrocystis Cienk. $\mathrm{He}$ also reported 2 other seagrass hosts of the parasite, Ruppia maritima L. and Zanichellia palustris L. and later found 2 additional algal hosts, Cladophora hirta Collins and Chaetomorpha linnum (Müll.) Kütz (Young 1943). 
Pokorny (1967) found Labyrinthula in a large proportion of eelgrass specimens (not necessarily diseased), and suggested that other conditions (salinity, insolation, temperature) also must have contributed to the epidemic. Pokorny (1967) did not distinguish Labyrinthula species, and it is possible that the species of Labyrinthula she frequently isolated from the eelgrass specimens was not the true pathogen. However, Rasmussen $(1973,1977)$ did not support the hypothesis that Labyrinthula was the pathogen causing eelgrass wasting disease for several reasons. Rasmussen concluded that Labyrinthula was not conclusively proven to cause the disease despite Renn's inoculation tests and microscopic observations (Renn 1934, 1935, 1936a). From the observations of Renn (1936a) and Young (1938b) that Labyrinthula was found ahead of the disease symptoms in the green portions of the leaf, Rasmussen (1977) concluded that Labyrinthula could be found in normal, healthy eelgrass and therefore suggested that it was probably not a primary pathogen but rather a secondary invader. Although Renn and Young did find Labyrinthula ahead of disease symptoms in plants, in tissue that was still apparently green, it is difficult to classify that as normal, healthy eelgrass. It is also possible that Rasmussen (1977) based his suggestion on the observation that non-pathogenic species of Labyrinthula have been isolated from many substrates including healthy eelgrass (Watson 1957. Johnson \& Sparrow 1961. Pokorny 1967).

Present research supports the hypothesis that a pathogenic species of Labyrinthula is the primary microorganism causing the present wasting disease of eelgrass (Short et al. 1987, Muehlstein et al. 1988). By experimental application of Koch's postulates, one species, Labyrinthula zosterae Porter and Muehlstein
(Muehlstein 1989, Fig. 1) is the only organism known to produce the characteristic darkened patches and streaks (Fig. 2) symptomatic of the wasting disease. In a thorough examination of the literature, the available information consistently supports Labyrinthula zosterae as the causative factor of the past epidemic wasting disease of eelgrass as well.

\section{IMPORTANCE OF EELGRASS (ECONOMIC AND ECOLOGICAL)}

Eelgrass Zostera marina was of great economic importance in the early part of the century. Cottam (1933a, c, 1934b, c, 1941), Cottam \& Addy (1947), Cottam \& Munro (1954), Lewis (1931, 1932), and Wheat (1962) reported extensively on the economic importance of eelgrass to industry. Thousands of tons of eelgrass were collected yearly in the early 1900's prior to the epidemic declines. Initially just the windrows of dead leaves were collected, but later the collection process expanded to mowing of intertidal eelgrass beds with a scythe (Lewis 1931, Cottam 1933a). The eelgrass, valued at $\$ 40$ ton $^{-1}$ (Lewis 1931) had a wide variety of uses including insulation, packing material, upholstery, mattress stuffing, sound proofing, bedding for domestic animals, and compost for fertilizer (Lewis 1931, 1932, Huntsman 1932, Cottam 1933a, c, 1934b, c, Blegvad 1934, Addy \& Aylward 1944, Cottam \& Munro 1954).

Migratory waterfowl were dependent on eelgrass beds as a major food source. Populations of brant geese Branta bernicla L. suffered severely with the decline in eelgrass populations (Ilchester 1933, Stevens 1933, McNab 1934, Moffitt \& Cottam 1941, Addy \& Aylward 1944, Cottam 1945, Ranwell \& Downing 1958, Tubbs \&

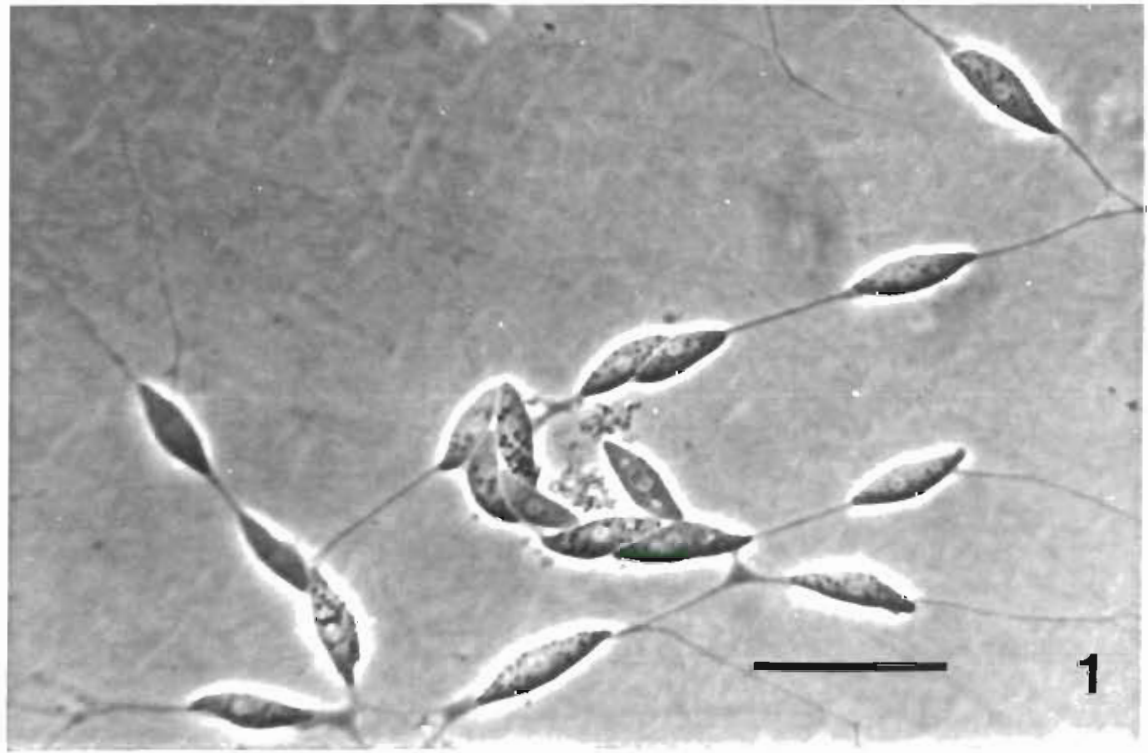

Fig. 1. Labyrinthula zosterae. Portion of a colony of cells on agar surface; bar $=25 \mathrm{~km}$ 


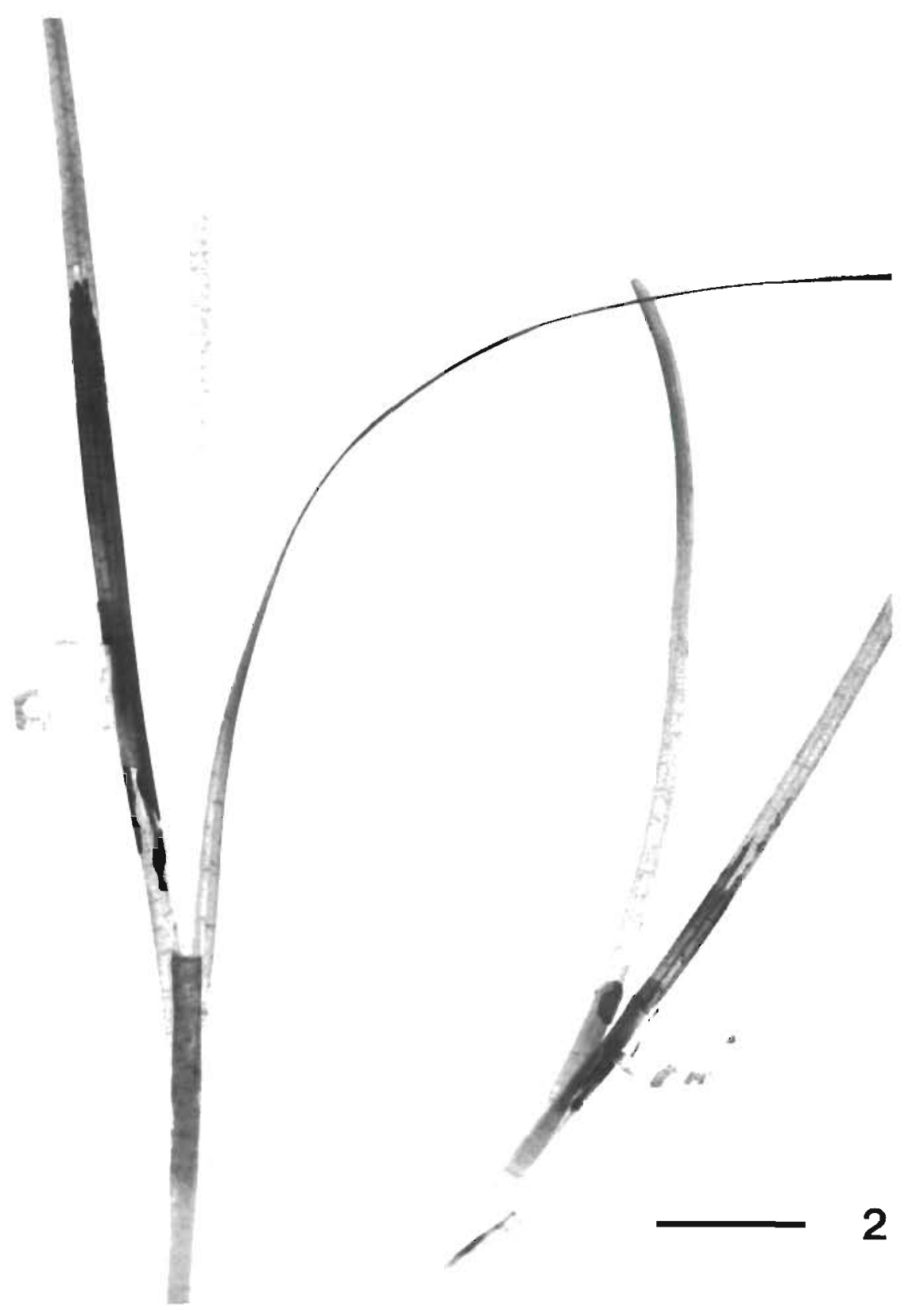

Fig. 2. Zostera marina wasting disease symptoms, $72 \mathrm{~h}$ after inoculation with axenic culture of Labyrinthula zosterae; bar $=25 \mathrm{~mm}$
Tubbs 1983). Because ca $80 \%$ of the diet of brant was eelgrass (Stevens 1933, Cottam 1934b, 1935a, Moffitt \& Cottam 1941), the bird's main food source disappeared with the wasting disease. In 1934 it was estimated that probably not more than $20 \%$ of the east coast brant populations survived the disappearance of eelgrass (Cottam 1934b, Moffitt \& Cottam 1941). In a December census for brant in the area of Barnegat Bay, New Jersey, populations of 28800 brant in 1927-1928 declined to 1980 in 1932-1933 (Cottam 1934b). Significant declines in brant populations were also noted in some bays along the California coast (Moffitt \& Cottam 1941). Populations of brant in Morro Bay, California, decreased from 11140 birds in 1939 to 6320 in 1941 , and this decline also was correlated with the decline in eelgrass in that bay. Numbers of brant were also reduced in Bodega and Tomales Bays. Some California bays actually had increases in brant populations during this period but there were definite changes in the feeding behavior of the birds, reflecting changes in the availability in food. By 1954, populations of brant along the east coast of North America had increased to 250000 (Cottam \& Munro 1954). These numbers still were considerably lower than population sizes prior to the wasting disease, but the brant populations appeared to be making a comeback (Cottam \& Munro 
1954). That populations of brant have also increased dramatically since the 1950's in the Netherlands, could be correlated with eelgrass recovery and a number of other factors (Tubbs \& Tubbs 1983).

Eelgrass is an important component of coastal environments and the eelgrass communities shelter a number of other organisms which were also severely affected by the widespread disappearance of the plants (Cottam 1933a, b, 1935a, Renn 1936a, Dexter 1944, Cottam \& Addy 1947. Wilson 1949, Cottam \& Munro 1954, Phillips 1982, Thayer et al. 1984). Declines in populations of clams, lobsters, crabs, scallops, cod, and flounder were noted (Cottam 1934b, C, Dexter 1944, Milne \& Milne 1951, Pokorny 1967). Unfortunately, actual statistics of declines or losses in fisheries are not available in the literature.

The eelgrass beds provide an important habitat for bay scallops Pecten irradians L. (Stauffer 1937, Dreyer \& Castle 1941, Thayer \& Stuart 1974). There was a corresponding decrease in numbers and occurrence of scallops with the disappearance of eelgrass after 1931 (Stauffer 1937, Dreyer \& Castle 1941, Cottam \& Addy 1947, Cottam \& Munro 1954, Hopkins 1957, Thayer \& Stuart 1974). Collections in Shinnecock Bay, New York, turned up few live specimens in 1935 to 1940 (Dreyer \& Castle 1941). In a complete invertebrate study in Woods Hole, Massachusetts, before and after the epidemic, there was a decrease in the total number of species found associated with the eelgrass habitat from 55 to 36 species (Stauffer 1937). Marshall (1947) reported an actual increase in abundance of bay scallops following the disappearance of eelgrass in the Niantic River, Connecticut. This may have been an unusual event, but nevertheless indicated a complex relationship between scallops and the eelgrass.

Not only are eelgrass communities important as nursery grounds but they are also important in stabilizing bottom sediments and acting as a filter for the water (Milne \& Milne 1951, Short \& Short 1984). With the loss of eelgrass in the 1930's and 1940's an effective breakwater was lost resulting in local coastal erosion (Cottam 1933c, 1934c, Cottam \& Munro 1954). An increase in water turbidity and pollution along the coast due to loss of eelgrass which was no longer there to act as a buffer was also evident (Cottam 1934C, Milne \& Milne 1951).

\section{OTHER SEAGRASS DECLINES}

Other declines of eelgrass have occurred since the wasting disease of eelgrass populations in the 1930's and 1940's although only one decline was directly linked to disease. Armiger (1964) reported disease in an unidentified species of eelgrass of Okahu Bay. New Zealand, with symptoms similar to eelgrass wasting disease. Labyrinthula was consistently associated with the diseased patches on the leaves.

Populations of eelgrass in Chesapeake Bay, Virginia, have suffered numerous declines in the 1970 's and 1980 's although the declines were not necessarily related to disease. Dramatic changes in distribution of eelgrass in the lower York River, Virginia, were documented in late 1973, primarily from destruction of the plants by cownose rays, Rhinoptera bonasus, feeding in the eelgrass beds (Orth 1975). Declines in Chesapeake Bay continued and in 1975 there was a massive die-back of eelgrass throughout the bay (Orth 1976). The summer of 1975 was the warmest for Chesapeake Bay since 1952 and it was possible that changes in the local weather conditions could account for the defoliation of the plants (Orth 1976). By 1983 the distribution and abundance of eelgrass and other aquatic plants had reached a record low (Orth \& Moore 1983). The causes were unclear but Orth \& Moore (1983) suggested the causes of the decline were related to the quantity and quality of light reaching the plants. It did not seem likely that disease was a factor since all submerged aquatic plants were affected. Areas of greatest reduction correlated with areas of greatest nutrient enrichment which resulted in. increased periphyton growth, thereby decreasing available light. In a comprehensive investigation of the decline of submerged aquatic vegetation in Chesapeake Bay, Kemp et al. (1983) also suggested nutrient enrichment and increased turbidity as likely causes.

The eelgrass populations in the Netherlands were affected by the wasting disease in the 1930's but recovered slowly during the 1940's, 1950's and 1960's (den Hartog \& Polderman 1975). After 1965, eelgrass in the Waddenzee began to decline and by 1973 , only 30 to $60 \%$ of the populations remained. Although some eelgrass plants growing in unfavorable conditions in this area exhibited symptoms similar to those observed in the 1930's wasting disease, increases in pollution were hypothesized to be the most likely cause of the declines (den Hartog \& Polderman 1975). Nienhuis (1983) reported declines in eelgrass populations in Grevelingen Lake in 1980 after a significant increase in size of eelgrass populations during the 1970's. Although Nienhuis (1983) reported that Van der Werff found Labyrinthula in the unhealthy eelgrass, Van der Werff (pers comm. to Nienhuis) also reported Labyrinthula in vigorously growing populations. From these observations, Nienhuis (1983) discounted the possibility of Labyrinthula causing the wasting disease of the 1930 's or the present decline of eelgrass, stating that Labyrinthula was not the cause of the decline but only a component of the decomposing activities.

Other seagrass declines also have been reported. Cambridge \& McComb (1984) reported a reduction in 
Posidonia sinuosa Cambridge et Kuo from 4200 to 900 ha during the period from 1954 to 1978 in Western Australia. This decrease corresponded with a period of industrial development of the area, resulting in an increase in nutrient rich effluents. Declines in the seagrasses resulted in decreases in species diversity and abundance as well as increased erosion along the beaches (Cambridge \& McComb 1984). P. oceanica (L.) Delile decreased significantly from 1950 to 1975 along the Mediterranean coast of France (Pérès \& Picard 1975). Causes of the decline were correlated with increases in the level of pollution and increases in clay sedimentation (Pérès \& Picard 1975). An endemic species of Labyrinthula, different from $L$. zosterae, has been suggested as the possible cause of a recent massive die off of Thalassia testudinum Banks ex König (turtle grass) in Florida Bay, Florida (Porter \& Muehlstein 1989).

\section{PRESENT STATUS OF EELGRASS}

Presently there exists a recurrence of eelgrass wasting disease with disease symptoms reported throughout North America and Europe (Short et al. 1986, 1987. 1988, Muehlstein et al. 1988). A major decline in eelgrass populations in New Hampshire and Maine was first noticed in 1984 (Short et al. 1986). Dexter (1985) reported another epidemic which decimated all eelgrass in the Cape Ann, Massachusetts, vicinity and indicated that it was the result of wasting disease but did not make any definitive observations. Additional collecting revealed that the symptoms of eelgrass wasting disease were present in populations along the east coast of the U.S., in France, England, the Netherlands, and in the San Juan Islands, Washington (Short et al. 1987, 1988, Muehlstein et al. 1988). Extensive field collections, laboratory disease tests (Fig. 2), and light and electron microscopy have conclusively supported the pathogenic species Labyrinthula zosterae (Fig. 1) as the causative factor (Short et al. 1987, Muehlstein et al. 1988, Muehlstein 1989). Although the cause of the 1930 's wasting disease epidemic was never clearly determined, work by Renn (1936a) and Young (1938a, 1943) clearly supported Labyrinthula as the etiological agent of eelgrass wasting disease. In a careful review of the literature and hypotheses surrounding the previous epidemic wasting disease, I feel that a pathogenic species of Labyrinthula was the cause of the 1930's epidemic and is the primary microorganism associated with the present decline of eelgrass. Although environmental influences, especially salinity, are likely to be important, it is unclear at this time how abiotic factors influenced the past decline or the present decline in eelgrass populations.
Acknowledgements. Special thanks to Dr D. Porter for his discussions, encouragement, and critical review of this manuscript and to Drs M. Darley, M. Fuller, B. Haines, C. Mims, and S. Newell for helpful suggestions. Assistance from Dr F. Short in locating some of the references for the review is greatly appreciated. This review is a portion of my dissertation submitted to the University of Georgia in partial fulfillment of the requirement for a $\mathrm{Ph}$. D. in Botany.

\section{LITERATURE CITED}

Addy, C. E., Aylward, D. A. (1944). Status of eelgrass in Massachusetts during 1943. J. Wildl. Mgmt 8: 269-275

Armiger, L. C. (1964). An occurrence of Labyrinthula in New Zealand Zostera. Z. J. Bot. 2: 3-9

Atkins, W. R. G. (1938). The disappearance of Zostera marina. J. mar, biol. Ass. U. K. 23: 207-210

Blegvad, H. (1934). An epidemic of the eel-grass (Zostera marina L.). Dan. Biol. Stat. Rep. 39: 1-8

Butcher, R. W. (1934). Zostera. Report on the present condition of eel-grass on the coasts of England based on a survey during August to October, 1933. J. Cons. perm int. Explor Mer 9: 49-65

Butcher, R. W. (1941). The distribution of Zostera (eelgrass. wigeon grass) and other seashore plants in relation to the migrations of wildfowl. Int. Wildfowl Inq. 1: 29-49

Cambridge, M. L., McComb, A. J. (1984). The loss of seagrasses in Cockburn Sound, Western Australia. 1. The time course and magnitude of seagrass decline in relation to industrial development. Aquat. Bot. 20: 229-243

Cottam, C. (1933a). Disappearance of eelgrass along the Atlantic Coast. Plant Dis. Rep. 17: 46-53

Cottam, C. (1933b). Recent observations on eelgrass conditions. Plant Dis. Rep. 17: 119-120

Cottam, C. (1933c). Eelgrass dying of a mysterious disease. Sci. News Lett. 24: 73

Cottam, C. (1934a). Past periods of eelgrass scarcity. Rhodora 33: $261-264$

Cottam, C. (1934b). The eelgrass shortage in relation to waterfowl. Trans. 20th Am. Game Conf. 20: 272-279

Cottam, C. (1934c). Eelgrass disappearance has serious effects on waterfowl and industry. Yearbook of Agriculture, U.S. Dept. Ag. p. 191-193

Cottam, C. (1935a). The present situation regarding eelgrass (Zostera marina). Wildlife Research and Management Leaflet BS-3. U. S. Dept. Ag., Bureau Biol. Survey, p. 1-7

Cottam, C. (1935b). Further notes on the past periods of eelgrass scarcity. Rhodora 37: 269-271

Cottam, C. (1938). Status of eelgrass (Zostera marina) on the north Atlantic coast, February, 1938. Wildlife Research and Management Leaflet BS-110. U. S. Dept Ag, Bureau Biol. Survey. p. $1-7$

Cottam, C. (1939). The eelgrass situation on the American Pacific coast. Rhodora 41: 257-260

Cottam, C. (1941). The eelgrass situation, fall 1940. Plant Dis. Rep. 25: 46-52

Cottam, C. (1945). Eelgrass conditions along the Atlantic seaboard of North America. Plant Dis. Rep. 29: 302-310

Cottam, C., Addy, C. E. (1947). Present eelgrass condition and problems on the Atlantic coast of North America. Transactions 12th North American Wildlife Conference, San Antonio, Texas, p. 387-398

Cottam, C., Munro, D A. (1954). Eelgrass status and environmental relations. J. Wildl. Mgmt 18: 449-460 
Cotton, A. D. (1933a). Disappearance of Zostera marina Nature Lond 132: 277

Cotton, A. D. (1933b). Disappearance of Zostera marina. Nature, Lond. 132: 483

den Hartog, C. (1987). 'Wasting disease' and other dynamic phenomena in Zostera beds. Aquat. Bot. 27: 3-14

deri Hartog, C., Polderman, P. J. G. (1975). Changes in the seagrass populations of the Dutch Waddenzee. Aquat. Bot. 1: $141-147$

Dexter, R, W. (1944). Ecological significance of the disappearance of eelcrass at Cape Ann, Massachusetts. J. Wildi Mgnnt. 8: 173-176

Dexter, R. W. (1945). A report on the eelgrass situation in the Annisquam (Massachusetts) and Mystic (Connecticut) tidewater rivers in the summer of 1945. Plant Dis. Rep. 29 $702-704$

Dexter, R. W (1946) The eelgrass situation in the Annisquam (Massachusetts) and Mystic (Connecticut) tidewater rivers in the summer of 1946. Fiant Dis. Rep. 30: $424-425$

Dexter, R.W. (1947). Status of eelgrass in the Annisquam tidal river and Menemsha saltwater pond in Massachusetts during the summer of 1947. Plant Dis. Rep, 31:448-449

Dexter, R. W. (1951). The eelgrass situation at Cape Ann, Massachusetts in the surmmer of 1951. Plant Dis. Rep. 35: $507-508$

Dexter, R. W. (1985). Changes in the standing crop of eelgrass, Zostera marina L, at Cape Ann, Massachusetts, since the epidemic of 1932. Rhodora 87: 357-366

Drever, W. A. Castle, W A. (1941). Occurrence of the bay scallop, Pecten irradians. Ecology 22: 425-427

Duncan, F. M. (1933). Disappearance of Zostera marina Nature, Lond. 132: 483

Fischer-Piette, E., Heim, R., Lami, R. (1932). Note préliminaire sur une maladie bactérienne des Zostères. C. r. hebd. Séanc. Acad. Sci. Paris 195: 1420-1422

Glemarec, M. (1979). Les fluctuations temporelles de peuplements benthiques liees aux fluctuations climatiques Oceanol. Acta 2: 365-371

Hopkins, S. H. (1957). Parasitism. In: Hedgpeth, J. W. (ed.) The Geological Society of America Memoir 67. Treatise on marine ecology and paleoecology. Vol 1, p. 413-428

Huntsman, A. G. (1932). Disease in eelgrass. Prog. Rep. Atl. biol. Stn Note 22. 5: 11-14

Ilchester. (1933). Swans and grass wrack. The Field Lond. 162 (4217): 1037

Johnson. T. W., Sparrow, F. K. (1961). Fungi in Oceans and Estuaries. J. Cramer, Weinheim

Kemp, W. M., Boynton, W. R., Twilley, R. W., Stevenson, J. C., Means, J. C. (1983). The decline of submerged vascular plants in upper Chesapeake Bay: Summary of results concerning possible causes. Mar. Technol. Soc, J. 17: 78-89

Lami, R. (1935). Travaux récents sur la maladie des Zostères. Rev. int. Bot. Appl. Agric. Trop. 15: 263-266

Lewis, H. F. (1931). The relation of Canada geese and brant to commercial gathering of eelgrass in the St. Lawrence estuary. Can. Field Nat, 45: 57-62

Lewis, H. F. (1932). The eelgrass situation on the Atlantic coast. Trans. 19th Am. Game Conf. 19: 411-423

Lewis, I. F., Taylor, W. R. (1933). Disappearance of Zostera in 1932. Rh.odora 35: 147-154

Lynch, J. J., Cottam, C. (1937). Status of eelgrass (Zostera marind on the North Atlantic Coast, January 1937. Wildlife Research and Management Leaflet BS-94. U. S. Dept. A.q., Bureau Biol. Survev, p. 1-15

Marshall, N. (1947). An abundance of bay scallops in the absence of eelgrass, Ecology 28: 321-322

Martin, A. C. (1954). A clue to the eelgrass mystery. Trans. 19th North Am. Wildl Nat. Resour. Conf. Washington, D.C. p. $44.1-449$

McNab. C. I. (1934). Maritime wildiowl situation. Rod Gun Can. 35: 20

McRoy, C. P. (1966). The standing stock and ecolocgy of eelgra.ss (Zostera marina L.) in Izembek Lagoon, Alaska. M. S. Thesis, Univ. of Washington, Seatte

McRoy, C. P., Bridges, K. W. (1974). Dynamics of seagrass ecosystems. Structure, functioning and management of ecosystems. Proc. 1st int. Congr. Ecol., The Hague, The Netherlands, September 8-14. Centre for Agricultural Publishing and Documentation, Wageningen, p. 374-375

Milne, L. J., Milne, M. J. (1951). The eelgrass catastrophe. Scient. Am. 184: 52-55

Moffitt, J., Cottam, C. (1941). Eelgrass depletion on the Pacific coast and its effect upon black brant. Wildlife Leaflet 204 , U. S. Dept Interior, Fish Wildl. Serv., p. 1-26

Mounce, I., Diehl, W. W. (1934). A new Ophiobolus on eelyeass. Call, J. Res. 11: 242-24:0

Muehlstein, L. K. (1989). The role of Labyrinthula zosterae in the wasting disease of eelgrass, Zostera marina. Ph. D. dissertation, University of Georgia, Athens

Muehlstein, L. K., Porter, D., Short, F. T. (1988). Labyrinthula sp, a marine slime mold producing the symptoms of wasting disease in eelgrass, Zostcra marina. Mar Biol. 99: $465-472$

Nienhuis, P. H. (1983). Temporal and spatial patterns of eelgrass (Zostera marina L.) in u former estuary in the Netherlands, dominated by human activities. Mar. Technol. Soc. J. 17: $69-77$

Olive, L. S. (1975). The Mycetozoans. Academic Press, New York

Orth, R. (1975). Destruction of eelqrass, Zostera Marina, by the cownose ray, Rhinoptera bonasus, in the Chesapeake Bay. Chesapeake Sci. 16: 203-208

Orth, R. (1976). The demise and recovery of eelgrass, Zostera marina in the Chesapeake Bay, Virginia. Aquat. Bot. 2: $141-159$

Orth, R. J., Moore, K. A. (1983). Chesapeake Bay: an unprecedented decline in submerged aquatic vegetation. Science, N. Y. 222: 51-53

Pérès, J. M., Picard, J. (1975). Causes de la raréfaction et de la disparition des herbiers de Posidonia oceanica sur les côtes Françaises de la Méditerranée. Aquat. Bot 1: 133-139

Petersen, H. E. (1933). Wasting disease of eelgrass (Zostera marina). Nature, Lond. 132: 1004

Petersen, H. E. (1934). Wasting disease of eelgrass (Zosterd marina). Nature, Lond. 134: 143-144.

Petersen, H. E. (1935). Preliminary report on the disease of the eelgrass (Zostera marina L.). Dan. Biol. Stn Rep. 40: 1-8

Petersen. H. E. (1936). Studies on a parasitic fungus in the eelgrass, Zostera marina L. Bot. Tidsskr. 43: 1-9

Phillips, R. C. (1982). Seagrass meadows. In: Lewis, R. R., III (ed.) Creation and restoration of coastal plant communities. CRC Press Inc., Boca Raton. Florida, p. 173-201

Pokorny, K. S. (1967). Labyrinthula. J. Protozool. 14: 697-708

Porter, D., Muehlstein, L. K. (1989). A species of Labyrinthula is the prime suspect as the cause of a massive die off of the seagirasss Thalassia testudinum in. Florida Bay. Mycol. Soc. Am. Newsletter 40 (1): 43

Ranwell, D. S., Downing, B. M. (1958). Brent goose (Branta bernicla L.) winter feeding pattern and Zostera resources at. Scolt Head Island, Norfolk. Anim. Behav. 7: 42-56

Rasmussen, E. (1973). Systematics and ecology of the Isefjord marine fauna (Denmark). Ophelia 11: 1-507

Rasmussen, E. (1977). The wasting disease of eelgrass (Zostera marina) and its effects on environmental factors and 
fauna. In: McRoy, C. P., Helfferich, C. (eds.) Seagrass ecosystems: a scientific perspective. Marcel Dekker Inc, New York, p. 1-51

Renn, C. E. (1934). Wasting disease of Zostera in American waters. Nature, Lond 134: 416

Renn, C. E. (1935). A mycetozoan parasite of Zostera marina. Nature, Lond. 135: 544-545

Renn, C. E. (1936a). The wasting disease of Zostera marina. I. A phytological investigation of the disease plant. Biol. Bull. mar biol. Lab., Woods Hole 70: 148-158

Renn, C. E (1936b). Persistence of the eelgrass disease and parasite on the American Atlantic coast. Nature, Lond. 138: $507-508$

Renn, C. E. (1937). The eelgrass situation along the middle Atlantic coast. Ecology 18: 323-325

Renn, C. E. (1942). Demonstration of Labyrinthula parasite in eel-grass from the coast of California. Science, N. Y. 95 122

Renouf, L. P. W. (1934). Zostera disease on the coast of county Cork, I. F. S. Nature, Lond. 133: 912

Setchell, W. A. (1922). Zostera marina in its relation to temperature. Science, N. Y 56:575-577

Setchell, W. A. (1929). Morphological and phenological notes on Zostera marina L. University California Publications in Botany, University of California Press, Berkeley, 14 (19): 389-452

Short, F. T., Ibelings, B., den Hartog, C. (1988). Comparison of a current eelgrass disease to the wasting disease in the 1930's. Aquat. Bot. 30: 295-304

Short, F. T., Mathieson, A. C., Nelson, J. I. (1986). Recurrence of the eelgrass wasting disease at the border of New Humpshire and Maine, USA. Mar Ecol. Prog. Ser. 29: 89-92

Short, F. T., Muehlstein, L. K., Porter, D. (1987). Eelgrass wasting disease: cause and recurrence of a marine epidemic. Biol. Bull. mar biol. Lab., Woods Hole 173: $557-562$

Short, F. T., Short, C. A. (1984). The seagrass filter: purification of estuarine and coastal waters. In: Kennedy, V S (ed.) The estuary as a filter Academic Press Inc, London, p. $395-413$

Southwaid, A. J., Butler, E. [., Pennycuick, L. (1975). Recent cyclic changes in climate and in abundance of marine life. Natuie, Lond. 253:714-717

Stauffer, R. C. (1937). Changes in the invertebrate community of a lagoon after disappearance of the eel-grass. Ecology 18: $427-431$

Steveris, N. E. (1933). United States of America: Disappearance of Zostera manna along the Atlantic coast of North America. Int. Rev. Agri. 24: 195-196

Stevens, N. E. (1935). Notes on Zostera marina in upper Buzzards Bay, Massachusetts. Plant Dis. Rep. 19: 232-233

Responsible Subject Editor: Professor S. Bonotto, Mol,

Belgium
Stevens, N. E. (1936a). Environmental conditions and the wasting disease of eelgrass. Science, N. Y 84: 87-89

Stevens, N. E. (1936b). Notes on the condition of Zostera marina in Buttermilk Bay, Massachusetts. Plant Dis. Rep. 20: $279-281$

Stevens, N. E. (1939). Environmental factors and the wasting disease of eelgrass. Rhodora $41 \cdot 260-262$

Stevens, N. E., Ellis, H. R., Stevens, R. B. (1950). Wasting and recovery of Zostera marina on the Atlantic coast of the United States. Plant Dis. Rep. 34: 357-362

Taylor, W. R. (1933). Epidemic among Zostera colonies. Rhodora 35: 186

Thayer, G. W., Kenworthy, W J., Fonseca, M. S. (1984). The ecology of eelgrass meadows of the Atlantic coast: a community profile, U.S. Fish Wildl. Serv. biol Rep. FWS/OBS84/02: 1-147

Thayer, G. W., Stuart, H. H. (1974). The bay scallop makes its bed of seagrass. Mar. Fish. Rev. 36: 27-30

Tubbs, C. R., Tubbs, J. M. (1983). The distribution of Zostera and its exploitation by wildfowl in the Solent, Southern England. Aquat. Bot. 15: 223-239

Tutin, T G. (1934). The fungus on Zostera marina. Nature, Lond. 134: 573

Tutin T G. (1938). The autecology of Zostera marina in relation to its wasting disease. New Phytol. 37: 50-71

Tutin, T. G. (1942). Zostera L. J. Ecol. 30: 217-226

Van der Werff, A. (1938). A new parasitic organism in Zostera marina. Chronica bot. 4: 498-499

Watson, S. W (1957). Cultural and cytological studies on species of Labyrinthala. Ph. D. thesis. University of Wisconsin, Madison

Wheat, M. C. (1962). Eelgrass: a controversial link in the chain of life in our marine waters. Conservationist 16: 28-30

Whelan, P. M., Cullinane, J. P. (1987). The occurrence of 'wasting disease' of Zostera in Ireland in the 1930's. Aquat. Bot. 27: 285-5289

Wilson. D. P. (1949). The decline of Zostera marina L. at Salcombe and its effects on the shore. J. mar biol. Ass. U.K. 28: 395-412

Young, E. L. (1937). Notes on the Labynnthula parasite of eelgrass Zostera marina. Bull. Mt Desert Isl. Biol. Lab., Directors Report for 1936 , p. 33-35

Young, E. L. (1938a). Recent investigation on the eelgrass problem: Preliminary report. Bull. Mt Desert Isl. Biol. Lab. Directors Report for 1937 , p. 26-28

Young, E. L. (1938b). Labyrinthula on Pacific coast eelgrass Can. J. Res., (Sect. C) 16: 115-117

Young, E. L. (1943). Studies on Labyrinthula. The etiologic agent of the wasting disease of eel-grass. Am. J. Bot. 30: 586-593

Zenkevitch, L. (1963). Biology of the seas of the U.S.S.R. Translated by $\mathrm{S}$. Botcharaskaya. George Allen and Unwin Ltd., Great Britain, p. 429

Manuscript first received: June 10,1989

Revised version accepted: September 12, 1989 